\title{
Effect of liner design, pulsator setting, and vacuum level on bovine teat tissue changes and milking characteristics as measured by ultrasonography
}

David E. Gleeson ${ }^{1}$, Edmond J. O'Callaghan ${ }^{1}$ and Myles V. Rath ${ }^{2}$

${ }^{1}$ Teagasc, Moorepark Research Centre, Fermoy, Co Cork, Ireland.

${ }^{2}$ Faculty of Agriculture, University College Dublin, Belfield, Dublin 4, Ireland.

Friesian-type dairy cows were milked with different machine settings to determine the effect of these settings on teat tissue reaction and on milking characteristics. Three teat-cup liner designs were used with varying upper barrel dimensions (wide-bore $\mathrm{WB}=31.6 \mathrm{~mm}$; narrow-bore $\mathrm{NB}=21.0 \mathrm{~mm}$; narrow-bore NB1 $=25.0 \mathrm{~mm}$ ). These liners were tested with alternate and simultaneous pulsation patterns, pulsator ratios (60:40 and 67:33) and three system vacuum levels (40, 44 and 50kPa). Teat tissue was measured using ultrasonography, before milking and directly after milking. The measurements recorded were teat canal length (TCL), teat diameter (TD), cistern diameter (CD) and teat wall thickness (TWT).

Teat tissue changes were similar with a system vacuum level of either $50 \mathrm{kPa}$ (mid-level) or $40 \mathrm{kPa}$ (low-level). Widening the liner upper barrel bore dimension from $21.0 \mathrm{~mm}(P<0.01)$ or $25.0 \mathrm{~mm}$ $(P<0.001)$ to $31.6 \mathrm{~mm}$ increased the magnitude of changes in TD and TWT after machine milking. Milk yield per cow was significantly $(P<0.05)$ higher and cluster-on time was reduced $(P<0.01)$ with the WB cluster as compared to the NB1 cluster. Minimum changes in teat tissue parameters were achieved with system vacuum level of $40 \mathrm{kPa}$ and $50 \mathrm{kPa}$ using NB and WB clusters, respectively. Similar changes in teat tissue and milk yield per cow were observed with alternate and simultaneous pulsation patterns. Widening pulsator ratio from 60:40 to 67:33 did not have negative effects on changes in teat tissue and had a positive effect on milk yield and milking time. Milk liner design had a bigger effect on teat tissue changes and milking characteristics than pulsation settings.

Irish Veterinary Journal

Volume 57: 289 - 296, 2004

\section{Introduction}

Changes in teat thickness are minimal when milk is removed via a catheter inserted in the teat canal (Hamann and Mein, 1990) or by hand (Gleeson et al., 2002). Therefore, an increase in thickness values after machine milking can be interpreted as a response of the teat tissue to the machine milking action.

\section{Correspondence:}

\section{David Gleeson}

Teagasc,

Moorepark Research Centre,

Fermoy,

Co. Cork,

Ireland.

Tel: +3532542269

Fax: +35325 42409

E-mail: davidgleeson@eircom.net
Key words

Cattle,

Machine milking,

Teat tissue,

Pulsation,

Milk liner,

Ultrasonography.
Physiological and pathological changes in the circulatory system associated with milking may decrease the efficacy of the defense systems. Zecconi (1992) observed higher infection rates of quarters and more ducts colonised in teats, where teat end thickness changed by $>5 \%$ than with teats showing less congestion. This decreased efficiency may be prolonged after

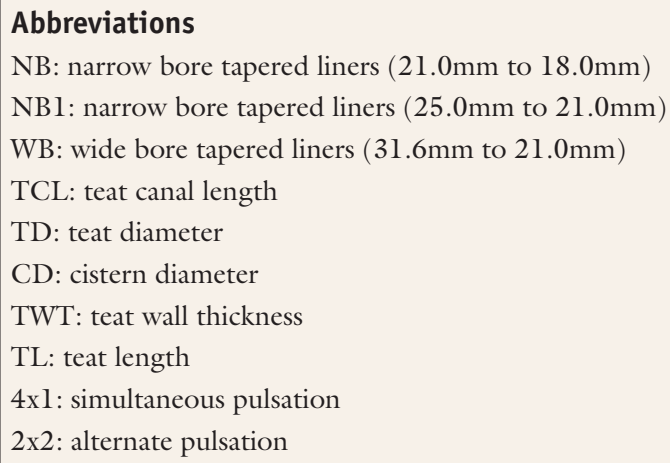




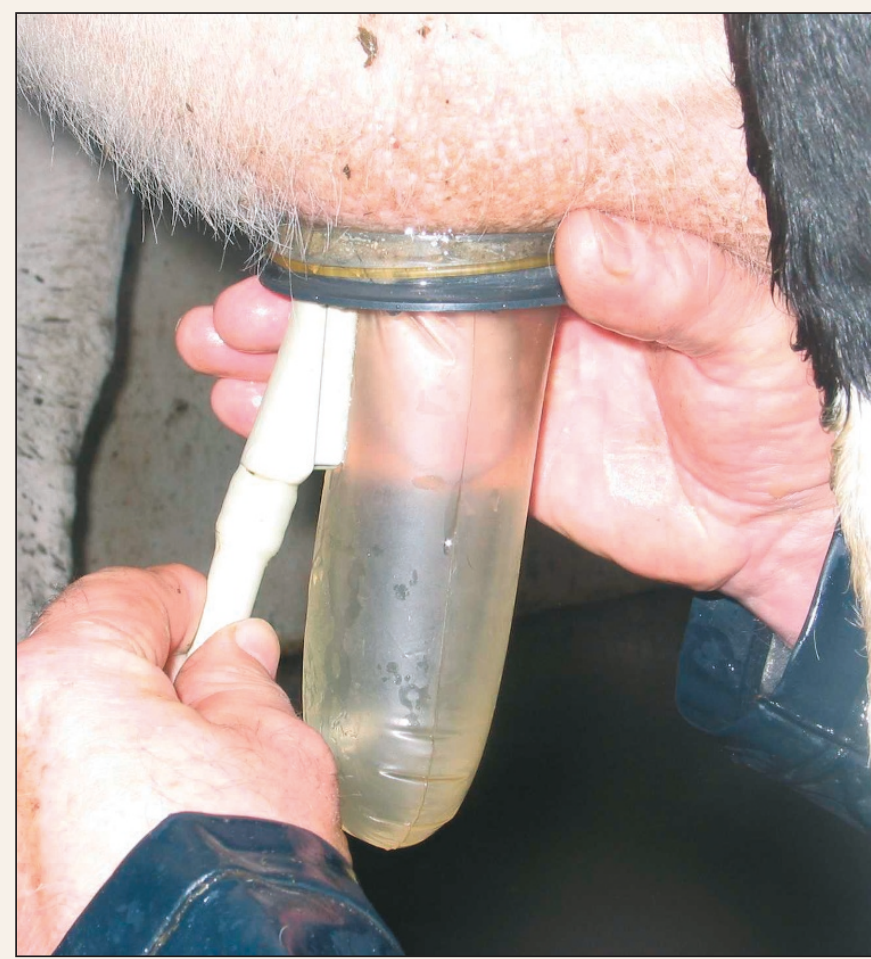

FIGURE I: Teat placed in a condom with the probe in vertical position against the teat wall.

milking at higher system vacuum levels (Hamann et al., 1993). Teat thickness changes of $15 \%$ were shown when system vacuum level in bucket milking plants was increased from 40 to $50 \mathrm{kPa}$. It has also been shown that full teat tissue recovery after machine milking may take many hours (Gleeson et al., 2002). This recovery time may also be influenced by milking systems using different liner types, which have been shown to result in varying degrees of teat canal penetrability (O'Brien, 1988). Liner designs commonly used in Ireland with wide upper barrel bore dimensions ( $31.6 \mathrm{~mm}$ tapered to $21.0 \mathrm{~mm}$ ) give higher milk yield (Gleeson and O'Callaghan, 2001) with reduced liner slips (O'Callaghan, 2001) than narrow bore type liners. Liners with wide upper barrel bore also have a higher cavity vacuum (O'Callaghan, 1998) and a higher teat-end vacuum (O'Callaghan, 2001) compared to narrow-bore liner types. Higher teat-end vacuum will increase peak milk flow-rate (Gleeson and O'Callaghan, 1999) but may also increase teat congestion or oedema. The physical properties of liners, such as wall thickness, mounting tension and rubber hardness, will also alter the cyclic pressure applied to the teat (Hamann and Mein, 1996). Therefore, liner design is an important factor in determining the effectiveness of pulsation.

Increasing pulsator ratio was demonstrated to induce a progressive increase in teat thickness, as did pulsation rate (Hamann et al., 1993). Experiments by Craig et al. (1991) and O'Callaghan (1998) have shown that a wide pulsator ratio results in faster milking than a narrow pulsator ratio. The interaction between liner design, vacuum conditions at the teat-end and pulsation

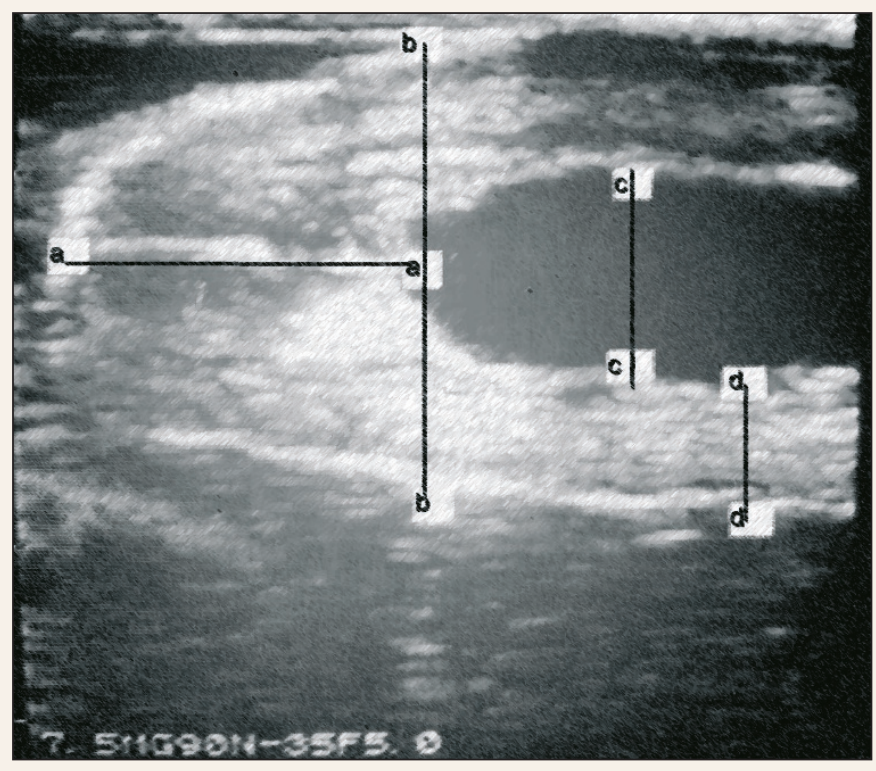

FIGURE 2: Measurement of teat canal length (a), teat diameter (b), cistern diameter (c), and teat wall thickness (d).

characteristics can influence the level of teat tissue reaction. Therefore, it is necessary to evaluate the effects of combinations of machine settings on the physiological status of teat tissue.

Changes in teat tissue induced by different milking systems have previously been measured using a simple spring-loaded calliper instrument or a modified electronic caliper device (Hamann et al., 1988). An alternative measurement technique is ultrasonography, which is non-invasive and is employed extensively in animal measurements. Banting (1998) used this technique for the examination of the bovine mammary gland for inflammation and fibrotic reactions of the udder. Spencer et al. (1996, 1997), Neijenhuis et al. (1999) and Gleeson et al. (2002) used this method to measure changes in bovine teat tissue after machine milking. Spencer et al. (1996) suggested that there was more variability with cutimeter measurements than with ultrasonic measurements. Neijenhuis et al. (1999) also concluded that ultrasonography was a good research instrument to monitor changes in teat tissue caused by machine milking. Ultrasonography allows measurement of a wide range of teat tissue parameters, including canal length, cistern diameter, teat wall thickness and teat diameter. In this paper we report the effects of liner design, pulsator settings, and pulsation characteristics with different system vacuum levels on machineinduced changes in teat tissue as measured using the ultrasonic technique.

\section{Materials and methods}

Teat tissue measurement procedures

An Aloka $500 \mathrm{v}$-ultrasound scanner with a $7 \mathrm{MHz}$ linear probe was used to measure changes in teat tissue on cow's teats. A plastic ring at the opening supported a Femidom-condom; this allowed it to be held in place with one hand, filled with warm water and placed around the cow's teat (Figure 1). A film of 


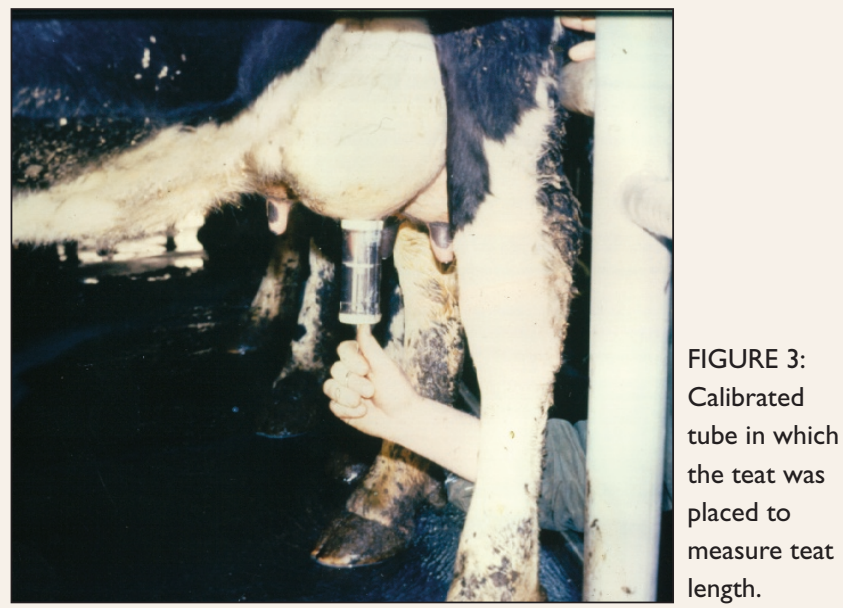

lubricating gel was placed on the probe head to improve contact with the condom. The probe was manipulated until a clear image of the teat appeared on the screen. When the picture was obtained, the image was frozen on screen. Images of teats were stored on videocassette and these were subsequently measured on screen. A purpose-designed software program was used to automatically record to file the distance between two points, which were marked using a ball mouse.

The teat parameters measured included teat canal length (TCL), teat diameter (TD), cistern diameter (CD), and teat wall thickness (TWT). TD was measured across the distal end of the teat canal; CD and TWT measurements were made at $10 \mathrm{~mm}$ from this point (Figure 2). Teats were washed with warm running water and dried with paper towels before the premilking measurement.

Values recorded for each teat parameter were taken on the leftsided front and rear teats of cows directly after milking and 15 minutes after milking. Post-milking values were compared to pre-milking values and the results presented as the mean changes (increases or decreases) in measurements. Teat length (TL) was measured using a calibrated transparent tube, into which the teat was placed (Figure 3 ). The ultrasonic method and procedure was outlined in detail by Gleeson et al. (2002).

\section{Liners designs and vacuum level - Experiment 1}

Six Friesian dairy cows were milked, with three milking systems and two cluster types, using a Latin Square design experiment (6 $\mathrm{x}$ 6). Cows were milked for three days per treatment, with day one used as an adjustment day. The cows were milked in a 14-unit, 80-degree side-by-side milking parlour, using $13.5 \mathrm{~mm}$ id long milk tubes, to a single $72 \mathrm{~mm}$-id milk-line situated at either $1.5 \mathrm{~m}$ above the cow standing (mid-level) or situated below the cow standing (low-level). The three milking systems had vacuum levels of $40 \mathrm{kPa}$ (low-level), $44 \mathrm{kPa}$ (low-level) and $50 \mathrm{kPa}$ (mid-level) and used a simultaneous pulsation pattern. Cluster one (WB) consisted of wide bore (31.6 to $21.0 \mathrm{~mm}$ ) tapered liners; it had a claw volume of $150 \mathrm{ml}$ and a cluster weight of $3.1 \mathrm{~kg}$. The second cluster type (NB) consisted of narrow bore $(21.0$ to $18.0 \mathrm{~mm}$ ) liners; it had a claw volume of
$323 \mathrm{ml}$ and a cluster weight of $1.65 \mathrm{~kg}$. The claw-piece designs were those normally supplied by manufacturers with these liner types. The WB cluster was used in experiments 1,2 and 3 and the NB cluster was used in experiments 1 and 2. Clusters were manually removed when milk flow-rate ceased in the cluster claw-piece. The pulsator ratio setting was $68: 32$ and the pulsation rate was $60 \mathrm{c} / \mathrm{minute}$ here and in subsequent experiments. Cows were milked at intervals of $17 \mathrm{~h}$ (overnight) and $7 \mathrm{~h}$ (daytime). Milk yield ( $\mathrm{kg}$ ) was recorded for each individual cow using Dairymaster Weigh-all electronic milk meters (E.P. Harty, Causeway, Co Kerry).

\section{Pulsator ratio and pulsation pattern (mid-level) -}

\section{Experiment 2}

Eight Friesian dairy cows were milked, with four milking treatments and two cluster types, using a Latin Square design experiment $(8 \times 8)$. Cows were milked for three days per treatment with day one used as an adjustment day in the same milking facility and using the mid-level milk-line as outlined for Experiment 1 . The system vacuum level setting was $49 \mathrm{kPa}$. The milking treatments consisted of pulsator ratio settings of $67: 33$ and 60:40 and simultaneous $(4 \times 1)$ and alternate $(2 \times 2)$ pulsation patterns. Pulse chamber ' $a$ ' and 'c' were similar for all treatments. Clusters were manually removed when milk flowrate dropped to $0.2 \mathrm{~kg} /$ minute as indicated by a light from the milk-meter software program. Milking characteristics, including milk yield ( $\mathrm{kg}$ ) and milking time (seconds), were recorded using the electronic milk meters at the morning milking, as outlined for Experiment 1.

\section{Pulsation pattern (low-level) - Experiment 3}

Eight Friesian-type dairy cows were milked with four milking treatments using a Latin Square design experiment $(4 \times 4)$ for three days per treatment with day one used as an adjustment day. Cows were milked in the milking facility as outlined for experiment 1 using a low-level milk-line situated below the cow standing and with a system vacuum level setting of $44 \mathrm{kPa}$. The milking treatments consisted of the WB cluster used in experiment 1 and 2 and a narrow-bore liner type with an upper barrel dimension of $25.0 \mathrm{~mm}$ tapered to $21.0 \mathrm{~mm}$ at the bottom $(\mathrm{NBl})$. A claw-piece with a volume of $275 \mathrm{ml}$ and a cluster weight of $1.65 \mathrm{~kg}$ as recommended by the cluster manufacturer was used with the NBI liner type. These cluster types were operated with $4 \times 1$ and $2 \times 2$ pulsation patterns and a pulsator ratio setting of $67: 33$. Individual cow milk yield $(\mathrm{kg})$ and milking time (seconds) were recorded using electronic milkmeters at the morning milking.

\section{Statistical analysis}

Measurements recorded for teat tissue, milk yield and milking time were subjected to analysis of variance test using Genstat (Genstat 5 Release 3.2, 1995). The analysis for teat tissue measurements was performed on the mean values of left-sided 


\begin{tabular}{|c|c|c|c|c|c|c|c|}
\hline \multirow{2}{*}{$\begin{array}{l}\text { Vacuum level - kPa } \\
\text { Cluster Type }\end{array}$} & \multicolumn{2}{|c|}{40 low-level } & \multicolumn{2}{|c|}{44 low-level } & \multicolumn{2}{|c|}{50 mid-level } & \multirow[b]{2}{*}{ s.e.d } \\
\hline & NB & WB & NB & WB & NB & WB & \\
\hline Canal length & 3.18 & 3.45 & 3.46 & 3.33 & 3.51 & 3.73 & 0.41 \\
\hline Canal length (15min) & 2.73 & 3.42 & 3.10 & 4.05 & 3.03 & 3.37 & 0.45 \\
\hline Teat diameter & $0.21^{\mathrm{b}}$ & $1.26^{\mathrm{a}}$ & $0.67^{\mathrm{ab}}$ & $1.55^{\mathrm{a}}$ & $0.52^{\mathrm{b}}$ & $0.19^{\mathrm{b}}$ & 0.47 \\
\hline Teat diameter $(15 \mathrm{~min})$ & $-0.03^{d}$ & $1.22^{\mathrm{a}}$ & $0.70^{\mathrm{ad}}$ & $1.50^{\mathrm{a}}$ & $0.68^{\mathrm{d}}$ & $0.06^{\mathrm{d}}$ & 0.32 \\
\hline Cistern diameter & -7.33 & -8.01 & -7.03 & -8.85 & -7.73 & -7.75 & 0.52 \\
\hline Cistern diameter (15min) & $-6.67^{\mathrm{b}}$ & $-7.82^{\mathrm{a}}$ & $-6.42^{\mathrm{b}}$ & $-8.40^{\mathrm{a}}$ & $-7.10^{\mathrm{b}}$ & $-7.62^{\mathrm{ab}}$ & 0.40 \\
\hline Wall thickness & 2.63 & 3.65 & 2.86 & 4.38 & 2.94 & 3.43 & 0.34 \\
\hline Wall thickness (15 min) & $2.30^{\mathrm{b}}$ & $3.43^{\mathrm{a}}$ & $2.78^{\mathrm{b}}$ & $3.90^{\mathrm{a}}$ & $2.95^{\mathrm{b}}$ & $3.20^{\mathrm{b}}$ & 0.24 \\
\hline Teat length & 11.62 & 8.75 & 11.17 & 5.17 & 10.42 & 9.12 & 1.83 \\
\hline Teat length (15 $\mathrm{min})$ & 4.50 & 2.92 & 4.67 & 0.67 & 4.42 & 2.50 & 1.43 \\
\hline Mean milk yield (kg) & 18.05 & 17.27 & 17.05 & 18.15 & 18.38 & 17.58 & 0.63 \\
\hline
\end{tabular}

front and rear teats for two morning recordings for each group for each period.

\section{Results}

\section{Experiment 1}

There was a significant interaction shown between vacuum level and cluster design for some teat parameters measured. A higher $(\mathrm{P}<0.05)$ increase in TD occurred with the WB cluster at a vacuum level of $44 \mathrm{kPa}$ (low-level) compared to measurements taken with a vacuum level of $50 \mathrm{kPa}$ (mid-level). These differences were still evident 15 minutes after cluster removal. The minimum changes in TD with WB were found at a vacuum level of $50 \mathrm{kPa}$ and with $\mathrm{NB}$ at a vacuum level of $40 \mathrm{kPa}$ (Table 1). There were no significant interactions between vacuum level and cluster type for TCL or TL or mean milk yield. However, teats tended to be longer after milking with the $\mathrm{NB}$ cluster compared to the WB cluster. The largest decrease $(\mathrm{P}<0.05)$ in $\mathrm{CD}$ and a corresponding increase $(\mathrm{P}<0.05)$ in TWT occurred with WB clusters at a plant setting of $44 \mathrm{kPa}$ ( 15 minutes after milking). There were no significant differences in changes to TCL, CD or TL between the three vacuum levels (Table la). However, higher changes in TD $(\mathrm{P}<0.01)$ occurred with a vacuum level of $44 \mathrm{kPa}$ as compared to the other two system vacuum levels. WB clusters increased TCL $(\mathrm{P}<0.01)$, TD $(\mathrm{P}<0.05)$, TL $(\mathrm{P}<0.01)$ TWT $(\mathrm{P}<0.001)$ and decreased CD $(\mathrm{P}<0.01)$ directly after milking; when compared to changes in teat tissue with $\mathrm{NB}$ clusters, these changes remained significant for all teat parameters fifteen minutes after milking. Changes in TWT was also higher $(\mathrm{P}<0.001)$ with the $\mathrm{WB}$ cluster directly after milking and fifteen minutes after milking. This increased

TABLE 1a: Effect of cluster type and plant vacuum level $(\mathrm{kPa})$ on mean teat-tissue changes (mm) directly after milking and 15 minutes later - Experiment 1

\begin{tabular}{|c|c|c|c|c|c|c|c|}
\hline & \multicolumn{3}{|c|}{ Cluster type } & \multicolumn{4}{|c|}{ Plant vacuum level } \\
\hline & WB & NB & s.e.d & 40 & 44 & 50 & s.e.d \\
\hline Canal length & 3.50 & 3.38 & 0.24 & 3.31 & 3.59 & 3.42 & 0.29 \\
\hline Canal length (15min) & $3.61^{\mathrm{a}}$ & $2.95^{\mathrm{c}}$ & 0.26 & 3.07 & 3.57 & 3.20 & 0.32 \\
\hline Teat diameter & $0.46^{\mathrm{a}}$ & $1.00^{\mathrm{b}}$ & 0.27 & 0.73 & 1.11 & 0.35 & 0.33 \\
\hline Teat diameter $(15 \mathrm{~min})$ & $0.45^{\mathrm{a}}$ & $0.98^{\mathrm{b}}$ & 0.18 & $0.60^{\mathrm{a}}$ & $1.10^{\mathrm{b}}$ & $0.37^{\mathrm{a}}$ & 0.22 \\
\hline Cistern diameter & $7.37^{\mathrm{a}}$ & $8.20^{\mathrm{c}}$ & 0.30 & -7.67 & -7.94 & -7.74 & 0.37 \\
\hline Cistern diameter (15min) & $7.95^{\mathrm{a}}$ & $6.73^{\mathrm{d}}$ & 0.23 & -7.25 & -7.41 & -7.36 & 0.28 \\
\hline Wall thickness & $3.82^{\mathrm{a}}$ & $2.81^{\mathrm{d}}$ & 0.19 & 3.14 & 3.62 & 3.18 & 0.24 \\
\hline Wall thickness (15 min) & $3.50^{\mathrm{a}}$ & $2.68^{d}$ & 0.14 & 2.69 & 3.34 & 3.06 & 0.17 \\
\hline Teat length & $11.07^{\mathrm{a}}$ & $7.68^{c}$ & 1.06 & 10.19 & 8.17 & 9.77 & 1.30 \\
\hline Teat length (15 min) & $2.03^{\mathrm{a}}$ & $4.53^{\mathrm{c}}$ & 0.82 & 3.71 & 2.67 & 3.46 & 1.01 \\
\hline Mean milk yield (kg) & 17.66 & 17.83 & 0.36 & 17.66 & 17.60 & 17.98 & 0.44 \\
\hline
\end{tabular}




\begin{tabular}{|c|c|c|c|c|c|c|c|c|c|}
\hline Pulsator ratio & $60: 40$ & $60: 40$ & $60: 40$ & $60: 40$ & $67: 33$ & $67: 33$ & $67: 33$ & $67: 33$ & \\
\hline Pulsation pattern & $2 \times 2$ & $4 \times 1$ & $2 \times 2$ & $4 \times 1$ & $2 \times 2$ & $4 \times 1$ & $2 \times 2$ & $4 \times 1$ & \\
\hline Cluster type & WB & WB & NB & NB & WB & WB & NB & NB & s.e.d \\
\hline Canal length & 2.98 & 3.16 & 2.72 & 2.47 & 2.39 & 2.69 & 2.80 & 3.14 & 0.41 \\
\hline Teat diameter & 1.47 & 1.76 & -0.36 & -0.09 & 1.10 & 1.04 & 0.40 & 0.04 & 0.38 \\
\hline Cistern diameter & -7.96 & -7.38 & -7.99 & -7.44 & -7.96 & -9.17 & -6.99 & -8.12 & 0.68 \\
\hline Wall thickness & 3.56 & 3.30 & 2.90 & 2.50 & 3.40 & 4.40 & 2.60 & 2.90 & 0.26 \\
\hline Teat length & 10.37 & 10.44 & 10.53 & 9.22 & 9.60 & 11.00 & 9.60 & 8.50 & 1.50 \\
\hline Milk yield & 16.93 & 17.02 & 16.45 & 15.36 & 17.62 & 17.26 & 16.35 & 16.39 & 0.42 \\
\hline Mean milking time & 495 & 488 & 650 & 629 & 484 & 468 & 581 & 572 & 25.8 \\
\hline
\end{tabular}

thickness in TWT corresponded with a reduction shown in CD. The milk yield harvested was similar for WB and NB cluster types. Changes in teat tissue measurements recorded postmilking tended to reduce fifteen minutes after cluster removal.

\section{Experiment 2}

The teat tissue changes and milking characteristics as a result of machine milking with eight treatments, including two pulsator ratios, two pulsation patterns and two cluster types, in a midlevel plant are outlined in Table 2. There were no significant differences between treatments for any of the teat parameters measured. The largest increase in TD occurred with the treatment containing WB clusters, 60:40 ratio and a $4 \mathrm{xl}$ pulsation pattern and the minimum changes in TD were observed with $\mathrm{NB}$ clusters using similar pulsator ratio and pulsation pattern. However, a lower milk yield was harvested per cow using the latter system. The highest $(\mathrm{P}<0.06)$ milk yield $(17.62 \mathrm{~kg})$ recorded per cow was obtained with the combination of WB clusters, $67: 33$ pulsator ratio and a $2 \times 2$ pulsation pattern, whilst the lowest milk yield $(15.36 \mathrm{~kg})$ was obtained with the treatment comprised of NB clusters, 60:40 pulsator ratio and $4 \times 1$ pulsation pattern. The shortest cluster-on time (468 seconds) per cow was observed with the treatment incorporating $\mathrm{WB}$, a ratio of $67: 33$ and a $4 \times 1$ pulsation pattern and the longest cluster-on time ( 650 seconds) was observed with the treatment comprising of $\mathrm{NB}$, a pulsator ratio of 60:40 and $2 \times 2$ pulsation pattern. The biggest reduction in $\mathrm{CD}$ with a corresponding largest increase in TWT occurred with the treatment comprised of $\mathrm{WB}, 67: 33$ pulsator ratio and $4 \mathrm{xl}$ pulsation pattern.

There were significant cluster $\mathrm{x}$ ratio interactions in relation to changes in TD $(\mathrm{P}<0.01)$ and $\mathrm{CL}(\mathrm{P}<0.05)$ and ratio $\mathrm{x}$ pattern interactions for changes to TWT $(\mathrm{P}<0.001)$ and $\mathrm{CD}(\mathrm{P}<0.01)$; there were no interactions evident for cluster $\mathrm{x}$ ratio, cluster $\mathrm{x}$ pattern or for ratio $x$ pattern (Table $2 \mathrm{a}$ ). Widening the pulsator ratio from $60: 40$ to $67: 33$ had no effect on TCL or TD and tended to increase the changes in $C D$ and resulted in a significant increase in TWT $(\mathrm{P}<0.001)$. The mean cow milk yield was also higher $(\mathrm{P}<0.05)$ with the pulsator ratio of $67: 33$. Cluster-on time was significantly shorter $(\mathrm{P}<0.01)$ at 527 seconds per cow with a pulsator ratio setting of $67: 33$ compared

TABLE 2a: Interaction of cluster type, pulsator ratio, pulsation pattern on teat tissue changes (mm), mean milk yield $(\mathrm{kg})$ and mean milking time (seconds) with mid-level milking - Experiment 2

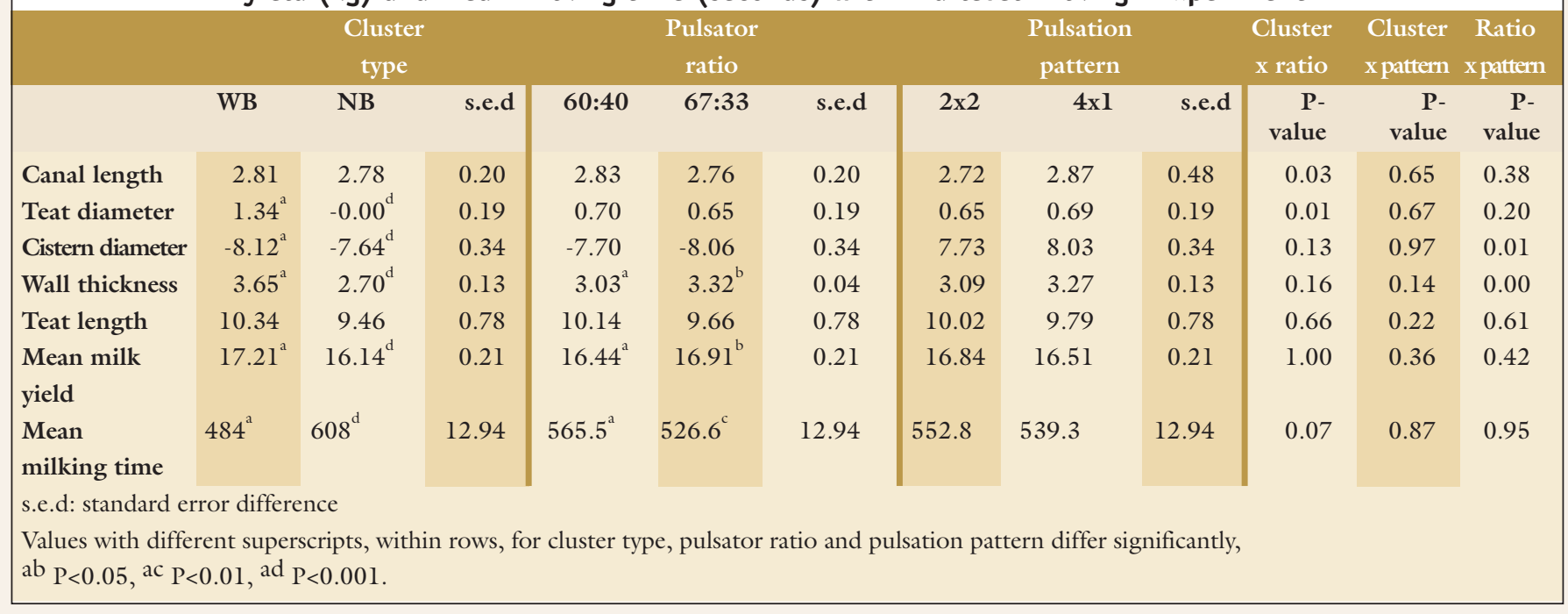


TABLE 3: Effect of pulsation pattern (alternate $=2 \times 2$, simultaneous $=4 \times 1$ ) with WB and NB cluster types on mean teat tissue changes $(\mathrm{mm})$, milk yield $(\mathrm{kg})$ and milking time (seconds) with low-level milking -

\section{Experiment 3}

\begin{tabular}{|l|c|c|c|c|c|}
\hline & $2 \times 2$ & $4 \times 1$ & $2 \times 2$ & $4 \times 1$ & \\
& N.B I & W.B & W.B & N.B I & s.e.d \\
\hline Canal length & 2.59 & 2.54 & 2.75 & 2.34 & 0.31 \\
Teat diameter & $-0.03^{\mathrm{a}}$ & $0.65^{\mathrm{c}}$ & $1.00^{\mathrm{c}}$ & $-0.20^{\mathrm{a}}$ & 0.29 \\
Cistern diameter & -6.87 & -7.50 & -7.30 & -6.88 & 0.95 \\
Wall thickness & 2.34 & 3.08 & 3.36 & 2.43 & 0.45 \\
Teat length & 8.47 & 10.84 & 9.31 & 9.53 & 0.99 \\
Mean milk yield & $13.79^{\mathrm{b}}$ & $15.09^{\mathrm{b}}$ & $14.1 \mathrm{~b}$ & $12.72^{\mathrm{a}}$ & 0.76 \\
Mean milking time & $517^{\mathrm{a}}$ & $595^{\mathrm{c}}$ & $444^{\mathrm{a}}$ & $674^{\mathrm{c}}$ & 58 \\
\hline s.e.d: standard error difference & & & & \\
Values with different superscripts, within rows, differ significantly, ab $\mathrm{P}<0.05,{ }^{\mathrm{ac}}$ \\
P<0.01.
\end{tabular}

to a cluster-on time of 566 seconds per cow with a ratio of 60:40. There was no significant difference in teat tissue changes or milking characteristics between pulsation patterns. When teat tissue changes were compared, increases in TD, CD and TWT associated with the WB clusters were significantly greater than those associated with NB clusters $(\mathrm{P}<0.001)$. Significantly higher $(\mathrm{P}<0.001)$ milk yield $(17.21 \mathrm{~kg})$ and lower $(\mathrm{P}<0.001)$ cluster-on time (484 sec) per cow, were shown with WB, compared to $\mathrm{NB}$ with a milk yield of $16.14 \mathrm{~kg}$ and a cluster-on time of 608 seconds per cow. There were no differences in changes to CL or TL between cluster types.

\section{Experiment 3}

The teat tissue changes and milking characteristics as a result of machine milking with alternate or simultaneous pulsation patterns with either WB or NBl cluster types in a low-level milking plant are outlined in Table 3. WB increased TD with either simultaneous or alternate pulsation patterns compared to $\mathrm{NBl}$ with either pulsation setting $(\mathrm{P}<0.01)$. There was no difference between treatments for changes in TCL and TL, but treatments containing WB tended to have larger increases in
CD and TWT compared to treatments using NBl. A significantly lower milk yield per cow $(\mathrm{P}<0.05)$ was recorded with $\mathrm{NBl}$ clusters and a $4 \times 1$ pulsation pattern compared to the other treatments. The longest cluster-on time per cow $(\mathrm{P}<0.05)$ was recorded with both $\mathrm{WB}$ and NB clusters using a $4 \mathrm{xl}$ pulsation pattern compared to clusters with a $2 \times 2$ pulsation pattern. Cluster $x$ pulsation pattern interactions were not observed (Table 3a). There were no differences shown in teat tissue changes or milk yield between pulsation patterns. However, a longer cluster-on time was observed with $4 \mathrm{xl}$ pulsation pattern compared to the $2 \times 2$ pattern $(\mathrm{P}<0.01)$.

Larger changes to TD $(\mathrm{P}<0.001)$ and TWT $(\mathrm{P}<0.05)$ were observed with WB compared to NB1. Milk yield per cow was significantly higher $(\mathrm{P}<0.05)$ and cluster-on time per cow was lower for $\mathrm{WB}(\mathrm{P}<0.01)$ compared to the $\mathrm{NBl}$ cluster.

\section{Discussion}

System vacuum levels of $50 \mathrm{kPa}$ (mid-level) and $40 \mathrm{kPa}$ (low-level) gave similar changes in teat tissue after machine milking. While previous studies have shown that vacuum level can have a great effect on teat thickness changes (Hamann et al., 1993), it was the interaction with cluster type that had the largest effect on changes to the teat diameter in this study. With system vacuum levels of $40 \mathrm{kPa}$ and $50 \mathrm{kPa}$ using $\mathrm{NB}$ and $\mathrm{WB}$ clusters, respectively, minimum changes were achieved in the teat tissue parameters measured. Both these system vacuum settings would result in claw vacuum levels within the ISO-guidelines (1996) of 32 to $40 \mathrm{kPa}$ measured during peak flow-rate. Widening the upper barrel bore of a milk-liner from 22.0 or 25.0 to $31.6 \mathrm{~mm}$ and a system vacuum level of $44 \mathrm{kPa}$ (low-level) increased the magnitude of teat tissue changes after milking, particularly TD. Higher teat-end vacuum associated with the WB liner type (O'Callaghan, 2001) and the higher system vacuum setting of $44 \mathrm{kPa}$ in a low-level milking system may explain the significant changes in teat tissue that have occurred. This result would also agree with the findings of Hamann (1992) that widening barrel bore would result in increased teat thickness. The increase in thickness may also be due to teats expanding after entering the

TABLE 3a: Interaction of cluster type and pulsation pattern on teat tissue changes $(\mathrm{mm})$, mean milk yield $(\mathrm{kg})$ and mean milking time (seconds) with low-level milking - Experiment 3

\begin{tabular}{|c|c|c|c|c|c|c|c|}
\hline & \multicolumn{3}{|c|}{ Cluster type } & \multicolumn{3}{|c|}{ Pulsation pattern } & \multirow{2}{*}{$\begin{array}{c}\text { Cluster } \\
\text { x pattern } \\
\text { P-value }\end{array}$} \\
\hline & N.BI & W.B & s.e.d & $2 \times 2$ & $4 \times 1$ & s.e.d & \\
\hline Canal length & 2.46 & 2.65 & 0.22 & 2.67 & 2.44 & 0.22 & 0.95 \\
\hline Teat diameter & $-0.12^{\mathrm{a}}$ & $0.83^{\mathrm{d}}$ & 0.21 & 0.49 & 0.22 & 0.21 & 0.69 \\
\hline Cistern diameter & -6.90 & -7.40 & 0.67 & -7.09 & -7.19 & 0.67 & 0.89 \\
\hline Wall thickness & $2.38^{\mathrm{a}}$ & $3.22^{\mathrm{b}}$ & 0.32 & 2.85 & 2.75 & 0.32 & 0.59 \\
\hline Teat length & 9.00 & 10.08 & 0.71 & 8.89 & 10.19 & 0.71 & 0.75 \\
\hline Milk yield & 13.25 & 14.60 & 0.54 & 13.95 & 13.90 & 0.54 & 0.08 \\
\hline Milking time & 596 & 520 & 41.2 & $481^{\mathrm{a}}$ & $635^{\mathrm{c}}$ & 41.2 & 0.94 \\
\hline \multicolumn{8}{|c|}{ s.e.d: standard error difference } \\
\hline
\end{tabular}


liner to fill the barrel of the liner as suggested by O'Callaghan (2001). Widening the upper barrel bore of a milk-liner can also result in a significant reduction in $C D$ after milking with a corresponding increase in TWT. This reduction is probably due to more complete milk evacuation. With all teat parameters measured, changes in teat tissue tended to reduce towards their pre-milking values 15 minutes after milking. However, it has been shown that full recovery of teat tissue can take many hours (Gleeson et al., 2002). Using either alternate or simultaneous pulsation patterns in mid-level or low-level milking systems had similar effects on teat tissue changes and on milk yield per cow. However, shorter milking times were observed with an alternate pulsation pattern and narrow-bore liners in a low-level milking system than with a simultaneous pulsation pattern and wide-bore liners. O'Callaghan (1998) showed that a higher teat-end vacuum occurs during the milking phase with the WB cluster in conjunction with simultaneous pulsation compared to the NB cluster in conjunction with an alternate pulsation pattern. This higher vacuum, in conjunction with higher vacuum at the teatend in a low-level milking system, may result in more teat penetration into the liner during milking and may result in longer cluster-on times and higher TD changes. Widening the pulsator ratio from 60:40 to 67:33 in a mid-level milking system did not have negative effects on teat tissue and had a positive effect on cow milk yield and milking time. Previous studies by Hamann and Mein (1996) showed increased teat thickness changes when the ' $b$ ' phase was increased from $40 \%$ to $70 \%$ in conjunction with changes in the 'a' phase of the pulsator. Changing the 'a' value of the pulsator graph has also been shown to change milking time (O'Shea et al., 1983). In this study, the pulse chamber phases 'a' and ' $c$ ' remained constant with the 'b' phase increasing from $42 \%$ to $49 \%$. In this study, cluster-on time was reduced with a pulsator ratio setting of $67: 33$ as compared to a ratio of $60: 40$. This result would agree with the findings of Craig et al. (1991) and O'Callaghan (1998) that machines with a wide pulsator ratio would milk faster than those with a narrow pulsator ratio. The teat tissue changes and milking characteristics observed for clusters and pulsation patterns in a low-level milking system were similar to those observed for these components in a mid-level milking system. All pulsation treatments applied had TD changes within the $\pm 5 \%$ level as suggested by Hamann and Mein (1996) as an indicator of the effectiveness of pulsation.

In a previous study by Hamann et al. (1993) teat length was reduced significantly by milking; whereas in all three experiments reported here, the mean teat length increased after machine milking. The increase in teat length after milking may be due to the increased cluster weight and higher cow milk yield with increased machine-on time.

The results of this study would agree with the findings of Brandsman (1968) that liner design has a bigger effect on milking characteristics than pulsation characteristics or vacuum level and liner design also appears to have a bigger effect on teat tissue changes than other machine settings.

\section{Acknowledgements}

The authors acknowledge Ms Francesca Neijenhuis, PR, Lelystad, Netherlands for advice and help with the ultrasonic technique. The authors also thank Mr Rene Van der Burgh, Hokeschool, Enschede, Netherlands for writing the computer software program for measurement of teat ultrasound scans.

\section{References}

Banting, A. (1998). Ultrasonographical examination of the mammary gland in cows with induced $S$. aureus mastitis: A criterion for prognosis and evaluation of therapy. Cattle Practice 6: 121-124.

Brandsman, S. (1968). The influence of vacuum level, pulsation ratio and type on milk flowrate (machine time) and completeness of milking. Proceedings of Symposium on Machine Milking, University of Reading, Reading, England. Edited by. F.H. Dodd. pp 1-59.

Craig, T.V., Force, D.K., Bremel, D.H. and Stressen, S. (1991). Effect of pulsation ratio, pulsation rate and teatcup liner design on milking rate and milk production. Journal of Dairy Science 74: 1243-1251.

Gleeson, D.E. and O'Callaghan, E. (1999). Effect of system vacuum level on bovine teat-tissue reaction and milking characteristics. Proceedings, Annual Meeting of National Mastitis Council. 38: 209 210.

Gleeson, D.E. and O'Callaghan, E. (2001). Effects of high and low levels of vacuum fluctuations on milk yield, teat-tissue condition, milk composition and new infection. Proceedings of Irish Grassland and Animal Production Association. 27: 65-66.

Gleeson, E., O'Callaghan, E.J. and Rath, M. (2002). Effect of milking on bovine teat tissue as measured by ultrasonography. Irish Veterinary Journal 55: 628-632.

Genstat, 5 Release 3.2. (1995). Lawes Agricultural Trust, Rothamsed Experimental Station.

Hamann, J. (1992). Physio-pathological aspects of machine milking. Proceedings of the International Symposium on Bovine Mastitis, Milan, pp53-67.

Hamann, J., Mein, G.A. and Wetzel, S. (1993). Teat tissue reactions to milking: Effects of vacuum level. Journal of Dairy Science 76: 1040-1046.

Hamann, J., Mein, G.A. and Burkhard, N. (1996). Recommended method for measuring changes in thickness of the bovine teat with spring-loaded calipers. Journal of Dairy Research 63: 309-313.

Hamann, J., Nipp, B. and Mein, G.A. (1988). Improving milk quality by improving teat condition: a new method of measuring teat tissue reactions to milking. Milchwissenschaft 43: 651-653.

Hamann, J. and Mein, G.A. (1990). Measurement of machineinduced changes in the thickness of the bovine teat. Journal of Dairy Research 57: 495-505.

Hamann, J. and Mein, G.A. (1996). Teat thickness changes may provide biological test for effective pulsation. Journal of Dairy Research 63: 309-313.

ISO 5707. (1996.) Milking machine installations - construction and performance. International Standard Organisation, Geneva, Switzerland. pp 47. 
Neijenhuis, F., Hogeveen, H. and Klungel G. (1999). Recovery time of cow teats after milking as determined by ultrasound scanning. Proceedings International Conference on Mastitis and Machine Milking, Cork, pp 39-41.

O'Brien, B. (1988). Milking Machine Factors Affecting Intra-unit Pathogen Transfer, Teat Condition And Occurrence Of Mastitis Infections In Bovines. Ph.D Thesis, National University of Ireland.

O'Callaghan, E.J. (2001). Influence of liner design on interactions of the teat and liner. Irish Journal of Agricultural and Food Research 40: 169-176.

O'Callaghan, E.J. (1998). Measurement of vacuum in the cluster using a milkflow simulator. Irish Journal of Agricultural Research 37: 137 (Abstract).

O'Callaghan, E.J. (1998). Effects of pulsation characteristics on machine yield, milking time and cluster stability. Irish Journal of Agricultural Research 37: 201-207.

O'Shea, P.E., O'Shea, J., O'Callaghan, E. and Gonzalez-Arraez, A. (1983). Effect of varying pulsation chamber vacuum phases on milking characteristics. In: Milking Machine Research at Moorepark, 1978-1982. Dublin: An Foras Taluntais. pp96-118.

Spencer, S.B., Griel, L.C. and Goldberg, J.J. (1997). Ultrasography of the bovine teat before and after milking. Proceedings at XXXII International Symposium on Animal Production: Advances in Technology, Accuracy and Management, Milan. page 7.

Spencer, S.B., Griel, L.C. and Goldberg, J.J. (1996). The use of ultrasonography to measure teat congestion. Proceedings of National Mastitis Council Meeting. 35: 172-173.

Zecconi, A., Hamann, J., Bronzo, V. and Ruffo, G. (1992). Machine-induced teat tissue reactions and infection risk in a dairy herd free of contagious mastitis pathogens. Journal of Dairy Research 59: 265-271. 